\title{
パッシブソーラーシステム試験家屋を用いた蓄熱床方式に 関する実験的研究
}

\section{1. 序}

前報9では，まず，一対の試験室から成る木造家屋の 概要と実験の計画および方法について述へ，次に，2つ の室の熱的性能が同一であることを確認した上で南側答 面積や天空，断熱雨戸など試験室の断熱と集熱に関する 基本的性能について検討した。その結果, 室の断熱性を 確保したうえで十分な日射を室内に取り入れれば，平均 室温はかなり上昇することが実験的に示された。しかし， そのままでは,室温は日射のあるときには高くなり過ぎ， 夜間や暄天日には低くなってしまうので，蓄熱をくふう することによって室温の変動を時間的にならすことが必 要である。

パッシブソーラーシステムの中で, 最も一般的に適用 されやすい方式は, 直接熱取得方式 (ダイレクトゲイン システム)である。これは, 日射を開口部から室内に直 接導入し，蓄熱体を施した床や壁，天井に蓄熱させ，日 射のない時間帯にその面から徐々に放熱させて室温を安 定させる方式である。

本報では，前報において熱的性能が同一であることが 確認された 2 つの試験室を用いて, 一方の $\mathrm{A}$ 室の床全 面に蓄熱体としてレンガを一様の厚さに積み重ね, 他方 の B 室は木造床として, まず, 両室の自然温度の比較 を行い，次に，室温形成の原因を熱量的な側面から調べ るためにレンガ休の蓄放熱量を推定して，それらより㷰 熱床方式の性能について検討したのでその結果を報告す る。このような蓄熱床方式について実験的に検討したも のとしては, これまで, 須永, 伊藤 ${ }^{11}$, 松尾, 井上ら ${ }^{81}$ の報告例がある。いずれも，蓄熱体にコンクリートを用 いており, 後者は数值シミュレーションの詳細な検証を

\footnotetext{
*東北工業大学 教授 $\cdot$ 工博

** 早稻田大学 教授.工博

*** 東北大学 助教授. 工博

***** 東北大学 助手. 工博

****** 東北大学 助手. 工博 (昭和 60 年 7 月 10 日原稿受理)
}

$\begin{array}{lllll}\text { 正会員 } & \text { 長 谷川 } & \text { 房 } & \text { 雄* } \\ \text { 正会員 } & \text { 木 } & \text { 村 } & \text { 建 } & \text { 一** } \\ \text { 正会員 } & \text { 吉 } & \text { 野 } & & \text { 博*** } \\ \text { 正会員 } & \text { 石 } & \text { 川 } & \text { 善 } & \text { 美**** } \\ \text { 正会員 } & \text { 松 } & \text { 本 } & & \text { 博***** }\end{array}$

も含んでいる。

なお，本報の結果を踏まえての各種蓄熱方式に関する 検討結果は，別途報告する予定である。

\section{2. 実駼概要}

試験家屋の平面図を図 1 に示す。A 室は，床に施し た断熱材（発砲ポリスチレン板，厚さ $10 \mathrm{~cm}$ ）の上にレ ンガを 3 段に積み重ね, $30 \mathrm{~cm}$ の厚さ（厳密には 31 $32 \mathrm{~cm}$ にばらついている) とした。ただし，レンガの置 き方が変更できるように，レンガとレンガの間にとくに 充填材は施していない。一方，B 室は従来の木造床を 想定し，外気に通じる空気層を設けてその上にベニヤ板 と厚さ $10 \mathrm{~cm}$ の断熱材から成る休を施した。両室の床 構成は図 2 のとおりである。このような床仕上げを行っ た結果, 両室とも, 天井高は $2.4 \mathrm{~m}$, 室容積は $33.8 \mathrm{~m}^{3}$ になった。

$\mathrm{A}$ 室で用いたレンガの密度は実測より $1,800 \mathrm{~kg} / \mathrm{m}^{3}$ で ある。したがって, 比熱を $0.2 \mathrm{kcal} / \mathrm{kg}^{\circ} \mathrm{C}$ とすると, $\mathrm{A}$ 室

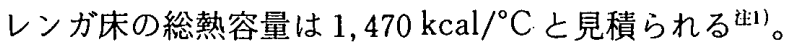
この熱容量は，B 室の木造床を構成するべ二ヤ板と断

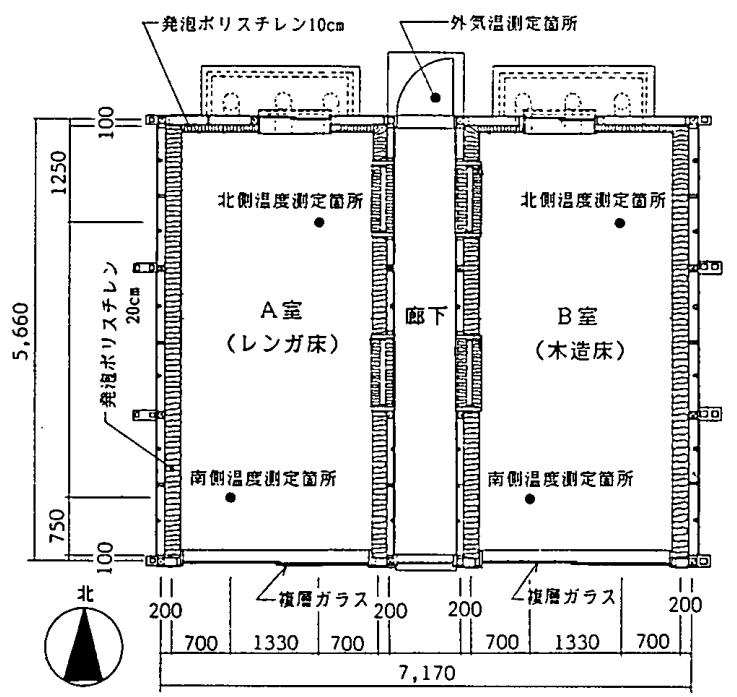

図 1 試験家屋平面図 


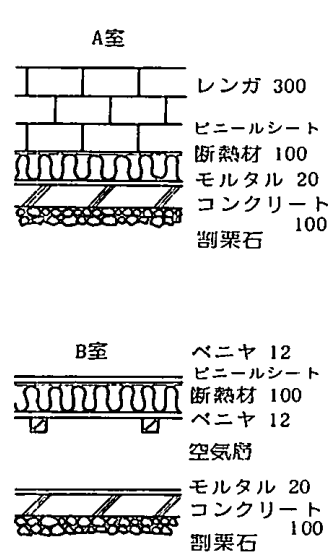

圆 2

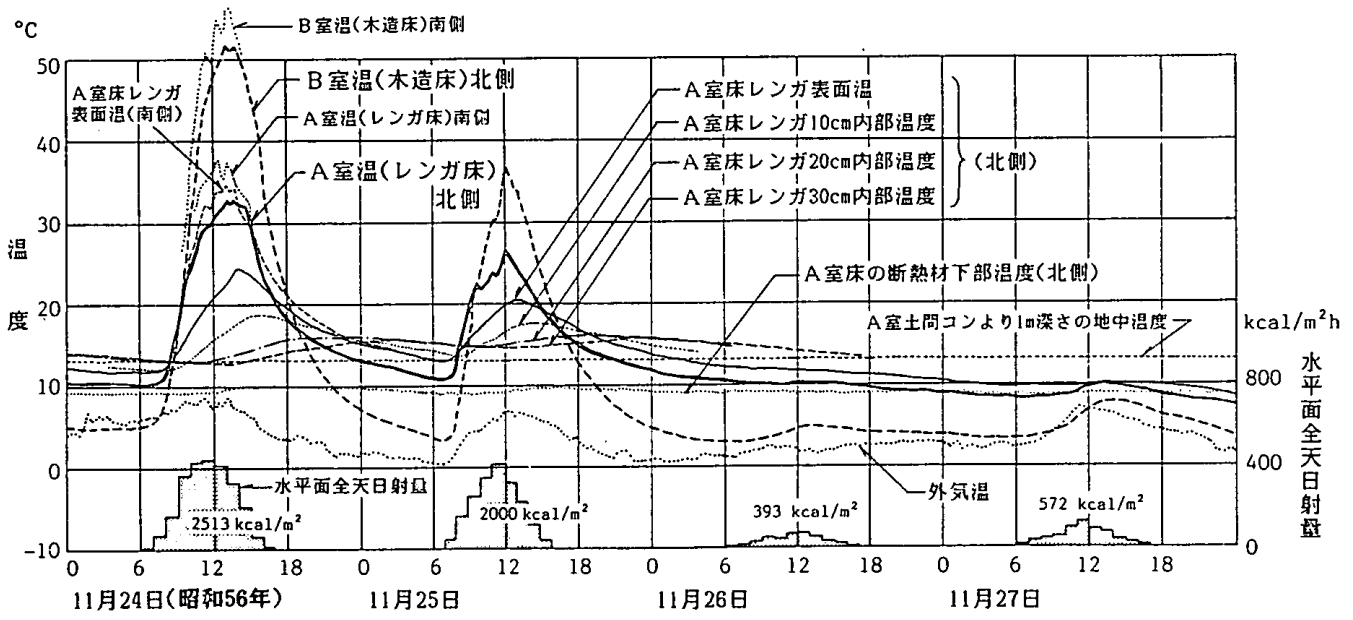

図 3 蓄熱床と木造床の温度変動の比較
熱材を合わせた総熱容量の約 21 倍に相当する䭛2。また， 温度の测定点としては, 前報9)で示した位置の他に, 図 1 に示す位置においてレンガ床の表面および 3 段に重ね た各層の点を加えた くにことわらない限り室内北側床上 $150 \mathrm{~cm}$ の位置の空 気温度を室温の测定値として代表させる。

レンガ床と木造床の比較実験は, 中間期（昭和 56 年 3 月 24 日：レンガ設置日〜 4 月 16 日), 夏期 (同 7 月 16 日 7 月 25 日), 冬期 (同 11 月 16 日：レンガ設置日 〜12月1日）に行った。また，レンガ床である A 室に ついての長期的な熱的性能の検討は, 基準室としてその 後 3 年間（昭和 56 年12月一昭和 59 年 12 月）固定して 実䲗を行った中の, 昭和 57 年 1 月〜 4 月および昭和 59 年 1 月〜2 月の测定結果に基づいている。

\section{3. 宾験结累}

\section{1 室内各部の温度変動}

図 3 に，冬期の実験として A 室の床にレンガを施し てから 9 日後の, 昭和 56 年 11 月 24 日から 27 日までの 測定結果を示す。

木造床である B 室の室温（室内北側, 床上 $150 \mathrm{~cm}$ の 空気温度）はこの期間の変動の範囲が $3 \sim 52^{\circ} \mathrm{C}$ と非常 に大きい。また, 日中から夕方, 夜間にかけて室温は急 激に降下し, 明け方には外気温付近まで達する。それに 対してレンガ床を設置した A 室の室温は, その変動の 範囲が 8 32 $2^{\circ} \mathrm{C}$ と 室よりかなり小さく, 明け方の最 低室温は前日が晴れていれば外気温より $10^{\circ} \mathrm{C}$, 辱って いる時でも $5^{\circ} \mathrm{C}$ 高く保たれている。一日の平均室温で みると, 晴天日においては両室の間でほとんど差はない が，死天日では明らかに蓄熱床の A 室の方が木造床の $\mathrm{B}$ 室より高くなっている。また, 室内南側の室温は, 両室とも北側より日中最大で $7 \sim 8^{\circ} \mathrm{C}$ 高く, それらの室 温の日中のピーク時は日射量のピーク時に対して 1 時間の遅れを示しているが，両室の間で差はほとんどな い。
この時期において，床面に日射の当る面積は南中時で 床面積の約 $54 \%\left(\right.$ 約 $7.5 \mathrm{~m}^{2}$ ) である。A 室のレンガ床 表面温度は，日中，日射の当る南側の方が日射の当らな い北側より高くその差は最大で $13^{\circ} \mathrm{C}$ に達するが，いず れもそれぞれの室温よりは低い波）。それに対して，夜 間や㖕天日における床表面温度は南側，北側ともほとん ど同じとなり，日射のある時とは逆に室温より高い。す なわち，レンガ床は晴天日の日中，日射熱を蓄熱し，夜 間や县天日にそれを放熱していることが推察される。

$\mathrm{A}$ 室北側のレンガ床表面から $10 \mathrm{~cm}, 20 \mathrm{~cm}$ 下（レン ガとレンガの間) および $30 \mathrm{~cm}$ 下 (レンガと断熱材の間) の温度は，11月 24 日，25日の 2 日間でみると，それぞ れ $12 \sim 19^{\circ} \mathrm{C}, 13 \sim 17^{\circ} \mathrm{C}, 13 \sim 16^{\circ} \mathrm{C}$ と室温や表面温に 比べて狭い範囲で変動している。また，そのピーク時は 日射量のピーク時に対して，それぞれ 3〜4 時間, 7〜10 時間，10〜12 時間の遅れを示しており，このことは， ただ単に重ねただけのレンガ休が蓄熱体として1つのま とまりをもって機能していることを示している。

一方, 床断熱材の下 (瞇熱材と土間コンクリートの間) の温度は $9 \sim 10^{\circ} \mathrm{C}$ と安定した変動を示し，この部分の 貫流熱流は，断熱材の熱伝導率を $0.03 \mathrm{kcal} / \mathrm{mh}^{\circ} \mathrm{C}$ とし て断熱材両側の温度変動から推定すれば最大でもおよそ $2.0 \mathrm{kcal} / \mathrm{m}^{2} \mathrm{~h}$ 以下と小さく，これより下の部分の室温 への影響は小さいものと思われる。

なお， $\mathrm{A}$ 室の土間コンクリート表面から深さ $1 \mathrm{~m} の$ 地中温度はこの期間 $13.5^{\circ} \mathrm{C}$ であり，一定であった。

\section{2 両室の熱的特性値の推定}

前報に示した松尾 ${ }^{5)}$ の方法に基づき，昭和 56 年 11 月 21 日一 25 日における毎時の室温，外気温の観測值およ び透過日射量の推定値を用いて，A，B両室における熱 損失係数 $K_{F}$ や室内の有効熱容量 $Q_{R}$ 等の熱的特性值を 算出した。この期間の透過日射量の日積算值や外気温お よび $\mathrm{AB}$ 両室温の日平均值は表 1 に示される通りであ る。計算結果を表 2 に示す。 
レンガ床である A 室の $K_{\mathrm{F}}$ は $3.09 \mathrm{kcal} / \mathrm{m}^{2} \mathrm{~h}^{\circ} \mathrm{C}$ ，木造 休の $\mathrm{B}$ 室は $2.66 \mathrm{kcal} / \mathrm{m}^{2} \mathrm{~h}^{\circ} \mathrm{C}$ となり，両室の差は小さ い。しかし， $Q_{R}$ の值は $\mathrm{A}$ 室が $832 \mathrm{kcal} /{ }^{\circ} \mathrm{C}, \mathrm{B}$ 室が $151 \mathrm{kcal} /{ }^{\circ} \mathrm{C}$ となり $\mathrm{A}$ 室の方が $\mathrm{B}$ 室の 5 倍以上になっ た。A 室の $Q_{R}$ は， $\mathrm{A}$ 室のレンガの熱容量の $56 \%$ に相 当する。したがって，この期間，使用されたレンガのす べてが室温変動の緩和に寄与しているとはいえず，図 3

表 1 計算期間（昭和 56 年 11 月 21 日〜25日）における透過日 射量と外気温および A, B 室温

\begin{tabular}{|c|c|c|c|c|}
\hline & 日搷算透過日射重 & 日平均外気温 & 日平均 $\mathrm{A}$ 室温 & 日平均 B室温 \\
\hline 11月21日 & $9,751 \mathrm{kcal} /$ 日 & $5.4^{\circ} \mathrm{C}$ & $18.8^{\circ} \mathrm{C}$ & $18.5^{\circ} \mathrm{C}$ \\
\hline 22 日 & 10,511 & 3.3 & 17.2 & 15.0 \\
\hline 23日 & 2,440 & 5.0 & 11.2 & 5.9 \\
\hline $24 \mathrm{~B}$ & 13,759 & 3.7 & 18.3 & 19.6 \\
\hline 25 日 & 9,980 & 2.8 & 16.4 & 13.0 \\
\hline
\end{tabular}

表 2 蓄熱床と木造床の室の熱的特性值の比較（昭和 56 年 11 月の実験より)

\begin{tabular}{|c|c|c|c|}
\hline & A 窒(レンガ床) & B室（木造床） & 㣁 考 \\
\hline 室温変徏事 $\lambda(1 / h)$ & 0.052 & 0.249 & ・斯算期間 \\
\hline 熱損失係数 $\mathrm{K}_{\mathrm{F}}\left(\mathrm{kca} \mid / \mathrm{m}^{2} \mathrm{~h}^{\circ} \mathrm{C}\right)$. & 3.09 & 2.68 & $\sim 11$ 月 $25 \mathrm{E}$ \\
\hline 有効熱容 $Q_{R}\left(\mathrm{kcal} /{ }^{\circ} \mathrm{C}\right)$ & 832 & 151 & 120 \\
\hline
\end{tabular}

表 3 計算期間（昭和 59 年 1 月）における透過日射量よ外気温 および A 室温

\begin{tabular}{r|c|c|c}
\hline & 日柦算透過日射里 & 日平均外気温 & 日平均 A 室洫 \\
\hline 1月18日 & $14,036 \mathrm{kcal} / \mathrm{\theta}$ & $-4.0{ }^{\circ} \mathrm{C}$ & $19.0{ }^{\circ} \mathrm{C}$ \\
$19 日$ & 3,405 & -3.0 & 5.4 \\
$20 日$ & 11,681 & -2.8 & 12.6 \\
$21 日$ & 9,385 & -1.0 & 10.4 \\
$22 日$ & 423 & -0.4 & 5.8 \\
$23 日$ & 12,690 & -0.5 & 14.4 \\
$24 日$ & 11,925 & -2.8 & 13.5 \\
$25 日$ & 9,885 & -1.5 & 13.8 \\
$26 日$ & 6,102 & -2.5 & 9.8 \\
$27 日$ & 12,496 & -0.8 & 15.1 \\
$28 日$ & 10,276 & -0.6 & 14.1 \\
$29 日$ & 11,005 & -1.4 & 15.2 \\
\hline
\end{tabular}

表 4 データとして抽出する 5 日間を変化させた場合の $K_{F}$ と $Q_{R}$ の算出結果

\begin{tabular}{|c|c|c|}
\hline $\begin{array}{c}\text { 計算期間 } \\
\text { （昭和59年） }\end{array}$ & $\begin{array}{c}\text { 熟强失係数 } K_{F} \\
\left(\mathrm{kca} \mid / \mathrm{m}^{2} \mathrm{~h}^{\circ} \mathrm{C}\right)\end{array}$ & $\begin{array}{c}\text { 有効熱容里 } Q_{\mathrm{P}} \\
\left(\mathrm{kca} /{ }^{\circ} \mathrm{C}\right)\end{array}$ \\
\hline 1月18日 1月 22 日 & 2.17 & 650.4 \\
\hline 1月19日〜1月23日 & 1.51 & 962.7 \\
\hline 1月 $20 \mathrm{E} \sim 1$ 月 $24 \mathrm{E}$ & 1.76 & 924.0 \\
\hline 1月21日〜1月25日 & 1.41 & 1237.5 \\
\hline 1月22日 1 月 $26 日$ & 1.39 & 1179.7 \\
\hline 1月 23 日 $\sim 1 月 27 日$ & 2.04 & 731.7 \\
\hline 1月 24 日 1 月 28 日 & 2.33 & 706.9 \\
\hline 1月25日～1月26日 & 2.17 & 676.1 \\
\hline
\end{tabular}

と後に示す図 9 のレンガ各部の温度変動をも含めて推定 すると，北側でしかも深い場所のレンガの室温変動への 影響は小さいものと推察される。なお， $\mathrm{A}$ 室の室温変 動率は 0.052 となり B 室の 1/5 であった。

ここで, $30 \mathrm{~cm}$ 厚レンガ床の A 室における昭和 59 年 1 月 18 日から 1 月 29 日までの毎時の観測データを用い て，1月18日より1日づつずらした 5 日間を対象とし た計算を行い，算出される $K_{F} や Q_{R}$ に対する計算期間 の影響について検討した。この期間の日積算透過日射量 および外気温, $\mathrm{A}$ 室温の日平均值は表 3 に示すとおり である。A 室の $K_{F}, Q_{R}$ の算出結果は表 4 のようになっ た。用いたデータによって $K_{F}$ は $1.39 〜 2.33$ ( $\mathrm{kcal} /$ $\left.\mathrm{m}^{2} \mathrm{~h}^{\circ} \mathrm{C}\right) ， Q_{R}$ は $650 \sim 1,238\left(\mathrm{kcal} /{ }^{\circ} \mathrm{C}\right)$ とそれぞれ異な る値に算出されている。これは，データとして用いた期 間の気候条件の違いによるものと思われる。また，表 4 によれば，抽出した 5 日間のデータの中に，2月22日 と 2 月 23 日のような極端に日射量の少ない晨天日とそ の逆の晴天日の組み合わせが連続して入っていると, 相 対的に $K_{F}$ は小さく $Q_{R}$ は大きく計算される傾向のある ことが判る。

次に，昭和 59 年 1 月 18 日から 2 月 16 日の 30 日間の 観測データを用いて，計算に用いるデータの長さを 1 日 づつ増やした場合の計算を行った。その結果を図 4 に示 す。 $K_{F}$ と $Q_{R}$ の値は, デー夕の長さが短いときにはそ れぞれ $3.0 \mathrm{kcal} / \mathrm{m}^{2} \mathrm{~h}^{\circ} \mathrm{C}, 350 \mathrm{kcal} /{ }^{\circ} \mathrm{C}$ 付近の值に算出さ れているが，日射の少ない日（1月22日）を含む5日 間を対象とした場合に，それらの值は大きく変化し，そ の後データの長さが長くなるほど, ある 1 つの值に近づ き安定してくる。1月18日から 30 日間のデー夕を用い たときの計算結果は, $K_{F}$ が $2.05 \mathrm{kcal} / \mathrm{m}^{2} \mathrm{~h}^{\circ} \mathrm{C}, Q_{R}$ が $709 \mathrm{kcal} /{ }^{\circ} \mathrm{C}$ となった。

以上から，実測値に基づいた，熱損失係数 $K_{F}$ と有効 熱容量 $Q_{R}$ の算出結果は, 室の熱的性能として, 計算期 間の気候条件に対応した特性を示す指標であることが推 定された。したがって，その算出にあたっては，用いる データがいかなる気候条件の組み合わせにあるかについ

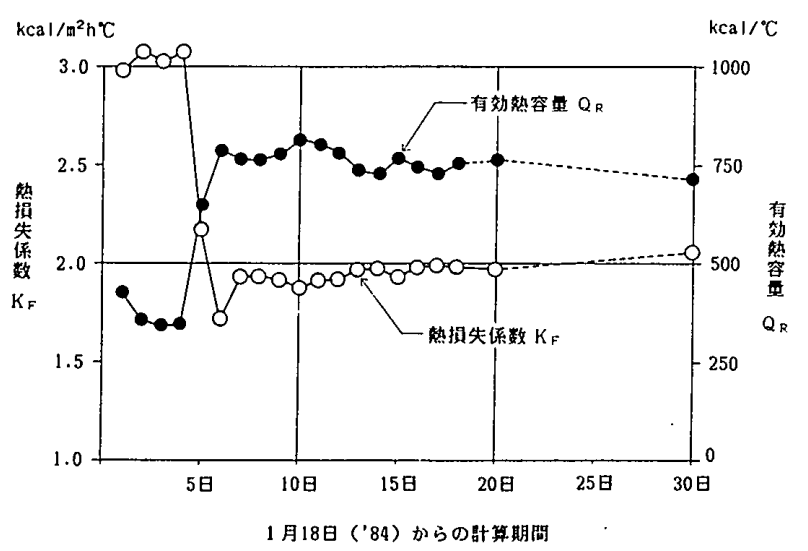

图 4 データの長さが異なる場合の $K_{F}$ と $Q_{R}$ の計算結果 
て注意するとともに，その適切な長さについては，今後 さらに検討する必要がある。

3.3 透過日射量に対する平均室温, 室温変動幅

ここでは, 一日の区切りを，日射の影響が最も弱くな る朝の 8 時として, 昭和 56 年における中間期, 夏期, 冬期の各実験日から, 4 月 2 日 - 14 日, 7 月19日～24日， 11 月 18 日 25 日の合計 27 日分のデー夕を用いて，日 平均室温と室温変動幅（日中の最高室温と翌日明け方の 最低室温の差）を算出し，透過日射量の日積算値との関 係を調べた。

図 5 に日積算透過日射量と外気温基準の日平均室温と の関係を示す。両者の相関は高く，相関係数は，A 室 で $0.87, B$ 室で 0.97 である。両室とも透過日射量が増 加すると平均室温が高くなり, 両室の間で䫓著な差はみ られない。しかし，レンガ休の A 室の方が木造床の B 室に比べてばらつきは大きく，また，透過日射量が大き いと平均室温は $\mathrm{B}$ 室の方が高くその逆の時は $\mathrm{A}$ 室の方 が高くなる。これは蓄熱の影響と思われる。

図 6 は, 日積算透過日射量と一日の室温変動幅の関係 を示したものである。両者の相関は非常に高く, $\mathrm{AB}$ 両 室とも相関係数は 0.95 以上である。レンガ床の $\mathrm{A}$ 室の 室温変動幅は，木造床の $\mathrm{B}$ 室よりはるかに小さく，年 間を通じて $\mathrm{A}$ 室は $\mathrm{B}$ 室の約 $1 / 2$ の変動幅に抑えられて いることが判る。すなわち，両室の回帰式によれば，透 過日射量 $1000 \mathrm{kcal} /$ 日あたりの変動幅の増分は，B 室 の $3.5^{\circ} \mathrm{C}$ に対して $\mathrm{A}$ 室は $1.7^{\circ} \mathrm{C}$ となっている。

次に, レンガ本の A 室について，上記のデータに加 えを昭和 57 年 1 月 7 日 4 月 4 日までの欠測日を除い た合計 87 日の観測データを用いて図 5, 図 6 と同様の 関係を示すと図 7，図 8 のようになる。外気温基準の日 平均室温と透過日射量, および室温変動幅と透過日射量 の間にはデータ数が少ない時とほぼ同様の回帰式が得ら れていることが判る。図7 の回帰式によれば，A 室の 外気温基準の日平均室温は, 透過日射量 $1000 \mathrm{kcal} /$ 日 の増加に対して約 $1^{\circ} \mathrm{C}$ 上昇する。これは，単位時間当 たり，単位床面積当たりに換算すると約 3.0 $\mathrm{kcal} / \mathrm{m}^{2} \mathrm{~h}^{\circ} \mathrm{C}$ に相当し，先に述べた，30日間の実測值に 基づいて推定した熱損失係数 $K_{F}$ と比べると，その約 1.4 倍であった。

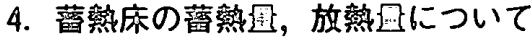

\section{1 蓄熱量, 放熱量の推定}

室内各部の温度の実測值を用いて，レンガ床の蓄熱量 と放熱量を以下の 3 とおりの方法によって算出した。す なわち，(1)レンガ床の熱容量を用いる方法，(2)レンガ休 のレスポンスファクターを用いる方法”，(3)室における 熱のつり合いから求める方法, である。本節では計算法 の概要を示し，その結果について考察する。なお，レン ガ㕅の温度は位置による分布が生じているものと思われ

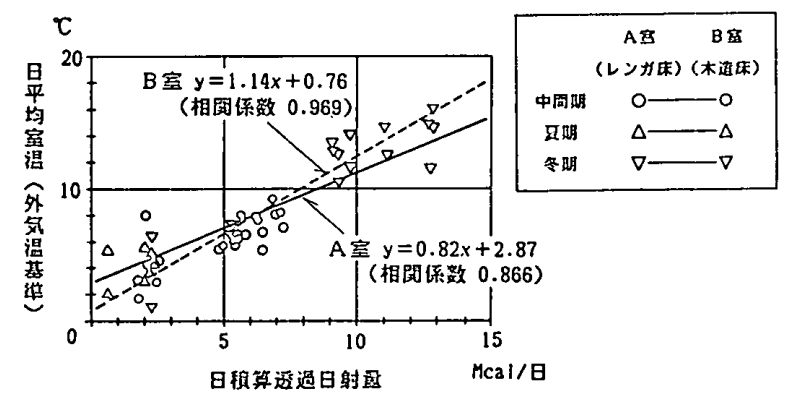

図 5 透過日射里亡日平均室温（外気温基準）の関係

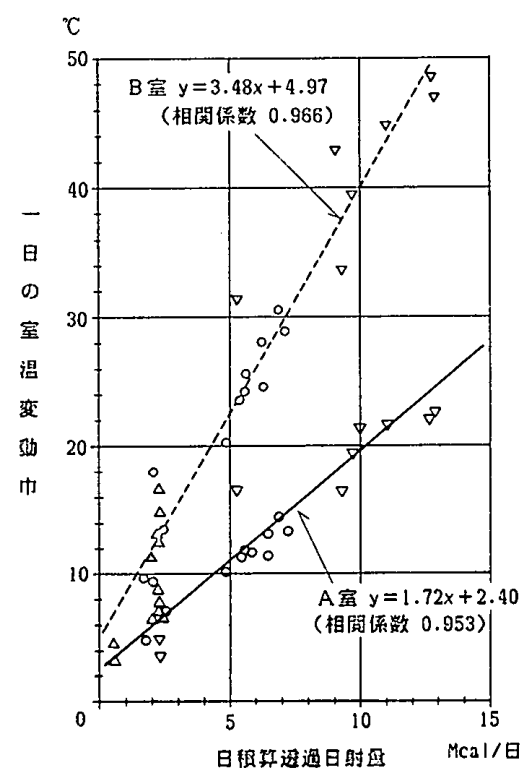

图 6 透過日射量と室温変動幅の関係

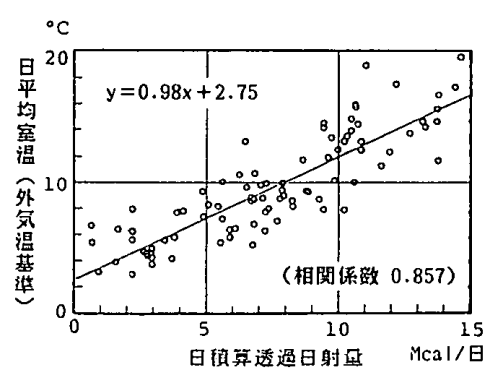

図 7 透過日射量と日平均室温（外気温基準）の関係（A 室： レンガ休)

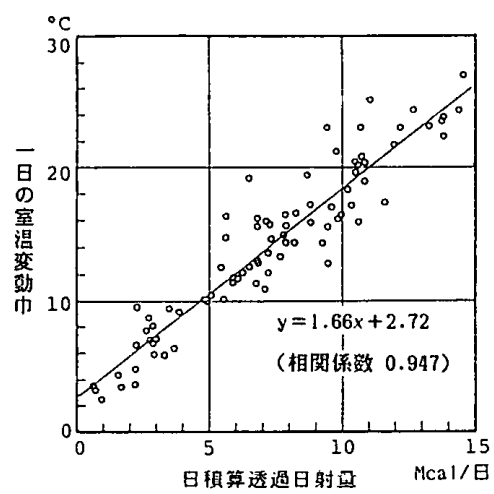

图 8 透過日射量と室温変動幅の関係 (A 室：レンガ椺) 
るが, 本実験ではレンガ各部の温度を, 図 1 に示した南 側之北側の場所でそれぞれ梁さ方向に 4 か所（表面, 深 さ $10 \mathrm{~cm}, 20 \mathrm{~cm}, 30 \mathrm{~cm}$ の各点) づつ測定しており, ここでは, それぞれの層の南北の平均值がレンガ床各層 の温度を代表しているものと考える。

\subsection{1 レンガ床の熱容量を用いる方法}

いま, 時刻 $n$ におけるレンガ内部 $k$ 点の温度を $\theta_{k} n$ とすれば，その時刻におけるレンガ床全体としての蓄熱 量 $D_{n}$ (負の量は放熱量) は

$$
D_{n}=c \rho \sum_{k=1}^{m} V_{k}\left(\theta_{k, n}-\theta_{k, n-1}\right)
$$

となる。ここに, $c:$ レンガの比熱 $\left[\mathrm{kcal} / \mathrm{kg}^{\circ} \mathrm{C}\right], \rho$ : レンガの比重量 $\left[\mathrm{kg} / \mathrm{m}^{3}\right]$ であり, $V_{k}$ は $k$ 点が代表し ているレンガの体積 $\left[\mathrm{m}^{3}\right], m$ は測定点数である。ここ では, レンガ床各部の温度変化より（1）式を用いて昭 和 56 年 11 月 24 日, 25 日の蓄放熱量を求めた。ただし, $c=0.2 \mathrm{kcal} / \mathrm{kg}{ }^{\circ} \mathrm{C}, \rho=1800 \mathrm{~kg} / \mathrm{m}^{3}$ とした。

図 9 に, レンガ床である $\mathrm{A}$ 室南側各部の温度変動（北 側については図 3 を参照) と,レンガ床の南北すべての 点の温度実測値より得られた蓄放熱量の計算結果を示 す。レンガ林は，日中日射熱を蓄熱し夜間放熱している ことが判る。日積算透過日射量に対する日積算蓄熱量の 割合は 11 月 24 日が $68 \% ， 25$ 日が $50 \%$ である。夜間 の放熱量はその日が晴天であれば時間当たり $300 〜 400$ $\mathrm{kcal} / \mathrm{h}\left(20 \sim 30 \mathrm{kcal} / \mathrm{m}^{2} \mathrm{~h}\right)$ となり，一日の合計は両日 とも約 $5500 \mathrm{kcal} /$ 日である。日中の蓄熱量には差がみ られたが, 夜間の放熱量は両日ともほぼ同じ值を示した。

なお，レンガ床における南側と北側の温度測定点が, それぞれ休を南北方向に 2 分した部分の温度を代表して いるものとして，この 2 日間の蓄放熱量を同様の方法に て南北別々に算出すると, 南側レンガと北側レンガの蓄 放熱量は，レンガ床全体の蓄放熱量のそれぞれ $60 \%$, $40 \%$ となっていた。

\subsection{2 レンガ床のレスポンスファクターを用いる方} 法

レンガのレスポンスファクターを用いて，時刻 $n$ に おけるレンガ休室内側表面での熱流 $D_{n}$ を算出し, 熱流 方向が表面から内部に向う時これを蓄熱量, その反対の 時放熱量とする。 $D_{n}$ は，表面における吸熱分と貫流分 の差し引きとなるから，レンガの両側の温度をそれぞれ $\theta_{A, n}, \theta_{B, n}$ として次式のように表される。

$$
D_{n}=A_{F} \sum_{j=0}^{n}\left(\theta_{A, n-j} x_{j}-\theta_{B, n-j} y_{j}\right)
$$

ここに， $x_{j}, y_{j}$ は，それぞれレンガの両側表面温励 振による吸熱, 貫流レスポンスファクターの第 $j$ 項, $A_{F}$ は床面積である。

レンガの密度, 比熱は前項と同じ值を用い, 熱伝導率 $0.53 \mathrm{kcal} / \mathrm{mh}^{\circ} \mathrm{C}$, 厚さ $0.3 \mathrm{~m}$ としてレスポンスファク
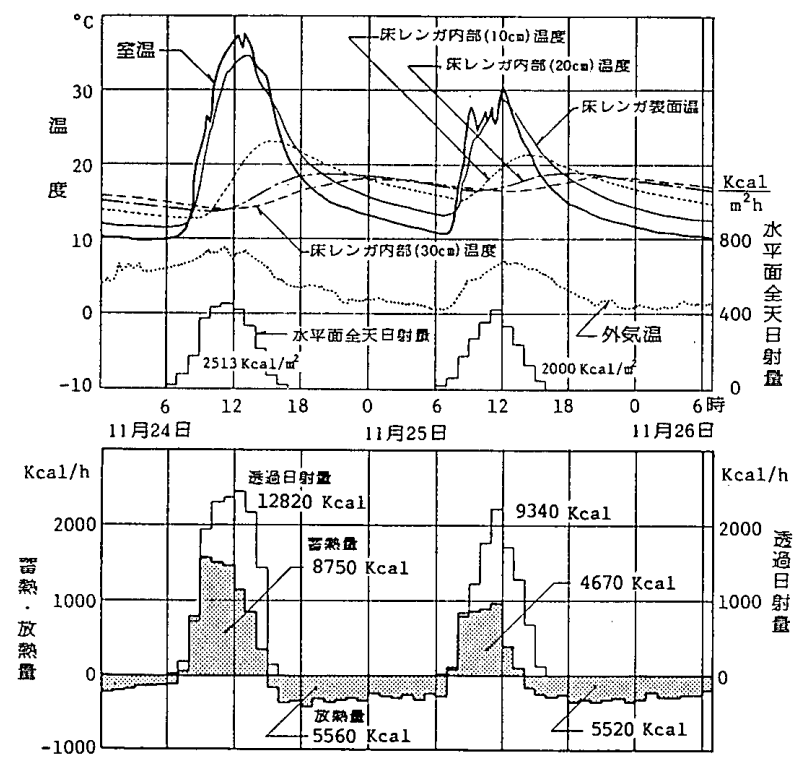

図 9 A 室各部（南側）の温度変動とレンガの熱容量を用いた 場合の蓄放熱量

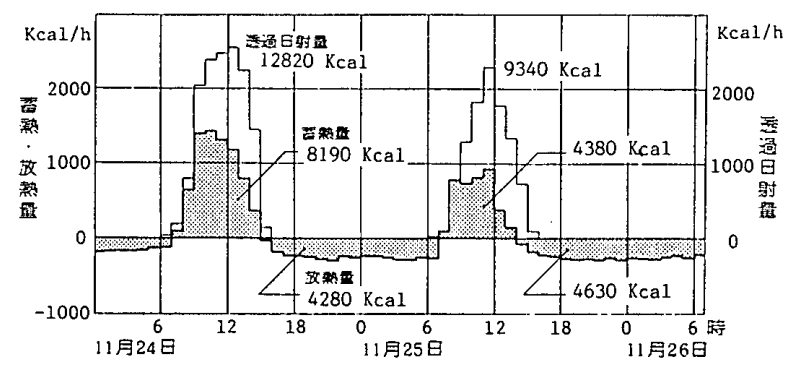

図 10 レンガのレスポンスファクターを用いた場合の蓄放熱量

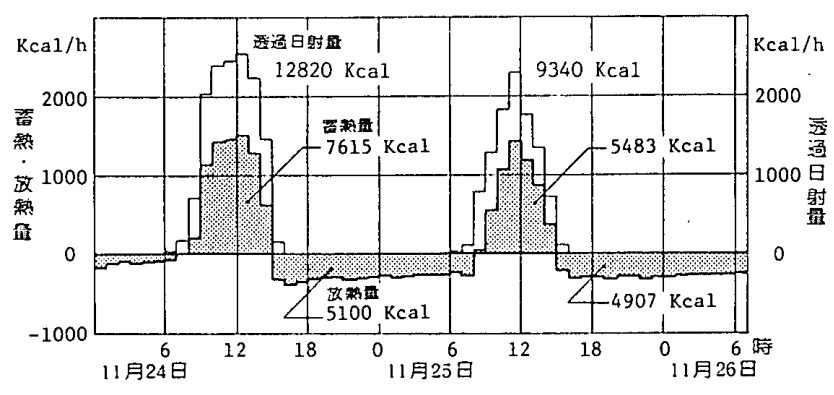

図 11 室における熱のつり合いより求めた蓄放熱量

ターを求めた。 $\theta_{A, n}, \theta_{\mathrm{B}, n}$ にはそれぞれレンガ表面温度, 最下層温度の実測值（南北の平均値）を用いて（2）式 より $D_{n}$ を算出すると図 10 のようになる。前項 (1) 式で計算される日積算量よりも，およそ，蓄熱量で $7 \%$, 放熱量で $20 \%$ 少なく計算されたが，傾向は良く合って いる。

\section{1 .3 室における熱のつり合いから求める方法}

壁体を通して移動する熱のうち，レンガ床からの分を 除いて室における熱のつり合いを考えると, 時刻 $n$ に おける損失熱之取得熱の差はレンガの蓄熱量または放熱 量 $D_{n}$ に相当するとみなすことができる。すなわち，透 過日射量を取得熱量として $D_{n}$ は次式のように書ける。 


$$
\begin{aligned}
D_{n}= & I_{n}-\left\{\sum_{i=1}^{N} A_{i} K_{i}\left(\theta_{i 1, n}-\theta_{i 2, n}\right)+0.3 n_{0} R\left(\theta_{R, n}-\theta_{0, n}\right)\right. \\
& \left.+0.3 R\left(\theta_{R, n}-\theta_{R, n-1}\right) / \Delta\right\} \cdots \cdots \cdots \cdots \cdots \cdots(3)
\end{aligned}
$$

ここに, $I_{n}$ : 透過日射量 $[\mathrm{kcal} / \mathrm{h}], A_{i}: i$ 壁面積 $\left[\mathrm{m}^{2}\right]$, $K_{i}: i$ 壁の熱コンダクタンス $\left[\mathrm{kcal} / \mathrm{m}^{2} \mathrm{~h}{ }^{\circ} \mathrm{C}\right], \theta_{i l, n}, \theta_{i 2, n}$ :それぞれ $i$ 壁の室内側, 外気側温度の実測值, $\theta_{R, n}$ : 室温, $\theta_{0, n}$ : 外気温, $N$ : 床を除く壁面数, $n_{0}$ : 換気回 数 $[1 / \mathrm{h}], R$ : 室容積 $\left[\mathrm{m}^{3}\right], \Delta$ : 時間間隔 ( $=1$ 時間) である。この方法では，壁体の熱の移動を定常的に吸っ ているので，誤差のでる可能性がある。

図 11 に, $n_{0}=0.1$ 回 $/ \mathrm{h}$ とした時の $D_{n}$ の計算結果を 示す。この場合, 毎時の透過日射量に対する蓄熱量の比 はほぼ一定となり, 先の結果とはやや異なる傾向を示し た。ただし，日積算值でみれば，蓄熱量，放熱量ともに 先の 2 つ方法による值の間に入っている。

\section{2 蓄熱量, 放熱量および透過日射量の相互関係}

前節では，レンガ休の蓄放熱量を各部温度の実測値に 基づく 3 種類の方法で推定した結果，それらがほぼ同様 の傾向となることを確認した。本節では, A 室に $30 \mathrm{~cm}$ 厚さのレンガ床を施して実験を行った昭和 56 年 7 月, 11月, 昭和 57 年 2 月 4 月のうちから 50 日分を取り出 し, 最も直接的で簡便である（1）式を用いて各実験日 のレンガの蓄熱量, 放熱量の日積算値を算出し, それら と透過日射量の日積算値および日平均室温などとの関係 をみた。なお,一日の区切りは朝の 8 時とした。

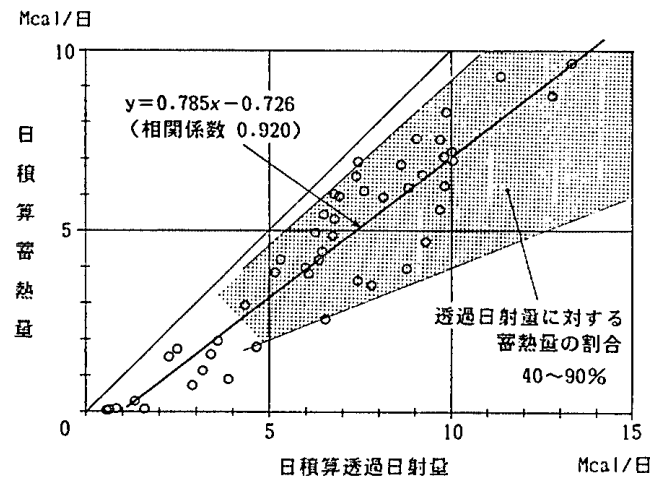

图 12 透過日射量と蓄熱量の関係 (1)

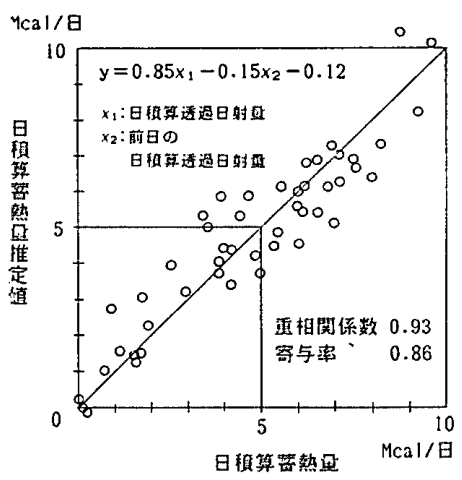

図 13 透過日射量と蓄熱量の関係（2）

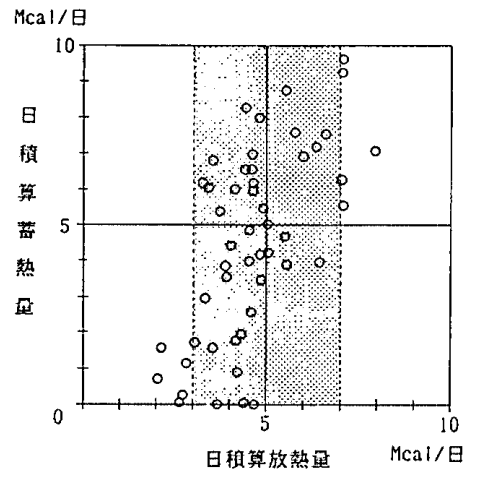

图 14 蓄熱量と放熱量の関係

\section{2 .1 透過日射量と蓄熱量の関係}

図 12 に，日積算透過日射量と日積算蓄熱量の関係を 示す。両者の相関は相関係数が 0.92 之高く, 透過日射 量の大きい日ほど蓄熱量が大きくなる傾向のあることが 示されている。これには季節の違いによる影響は認めら れなかった。透過日射量に対する蓄熱量の割合は，日射 量が $5000 \mathrm{kcal} /$ 日以上の範囲で $40 \%$ ～90\%の間にば らついており，平均すると約 $70 \%$ である。また，透過 日射量が $2000 \mathrm{kcal} /$ 日以下のような日はほとんど蓄熱 されないことが判る。

試みに前日の透過日射量を説明変数に加えて重回帰分 析を行うと，相関係数はわずかながら上昇した。このと きの蓄熱量の計算値と推定值を比較してみると図 13 に 示される通りとなる。前日の透過日射量は $t$ 検定にお いて裹却率 $1 \%$ で有意となり，偏回帰係数によれば当 日の蓄熱量に対して負に働いている。すなわち，前日の 透過日射量が多ければ当日の蓄熱量は少なくなり，前日 の透過日射量が少なければ当日の蓄熱量は多くなる。こ のことは，先に考察した，室の有効熱容量と気候条件の 関係にも通ずるところと思われる。

\section{2 .2 蓄熱量と放熱量の関係}

図 14 に厚さ $30 \mathrm{~cm}$ のレンガ床における日積算蓄熱量 と日積算放熱量の関係を示す。放熱量は蓄熱量に比べて 狭い範囲に分布しており，蓄熱量が 0 10000 kcal/日 の間でばらついているにもかかわらず，放熱量は 3000 ～7000 kcal/日の間に全データの $85 \%$ が入っている。 これは，蓄熱量は主に当日の日射量に大きく左右される のに対して，放熱量は当日の蓄熱だけでなく過去の蓄熱 の影響を受けるためであると推察される。図 9 図 11 で示されたように，夜間の放熱量がその日の日中の蓄熱

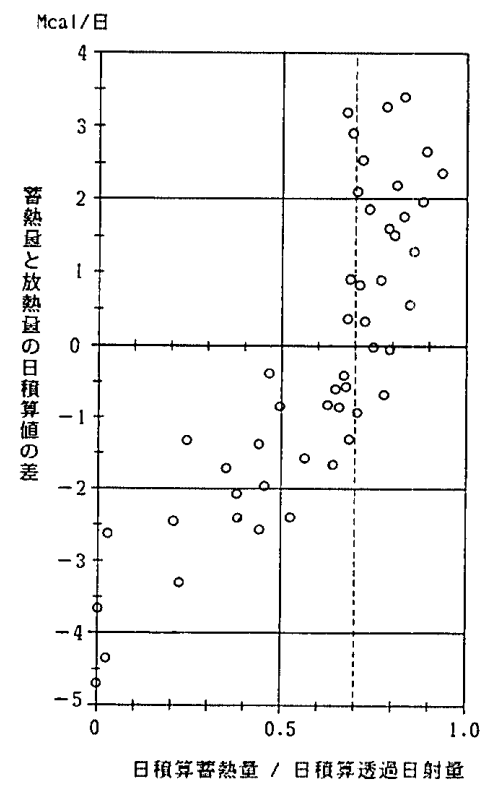

図 15 蓄放熱量の一日の差と透過日射量に 対する蓄熱量の割合との関係 


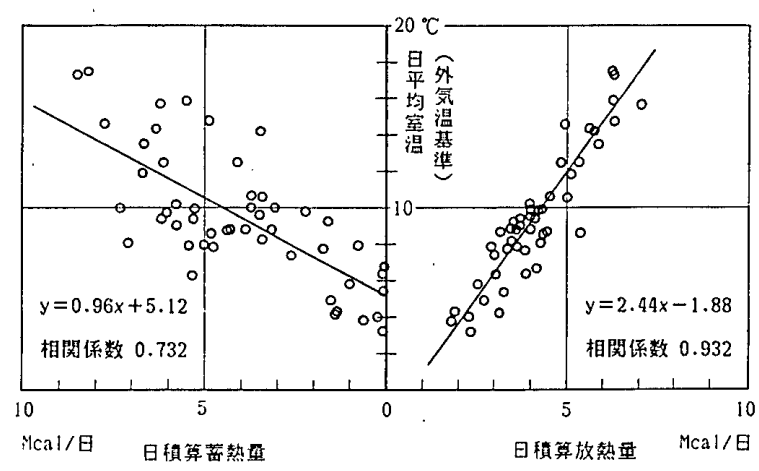

図 16 外気温基準の日平均室温と日積算蓄放熱量の関係

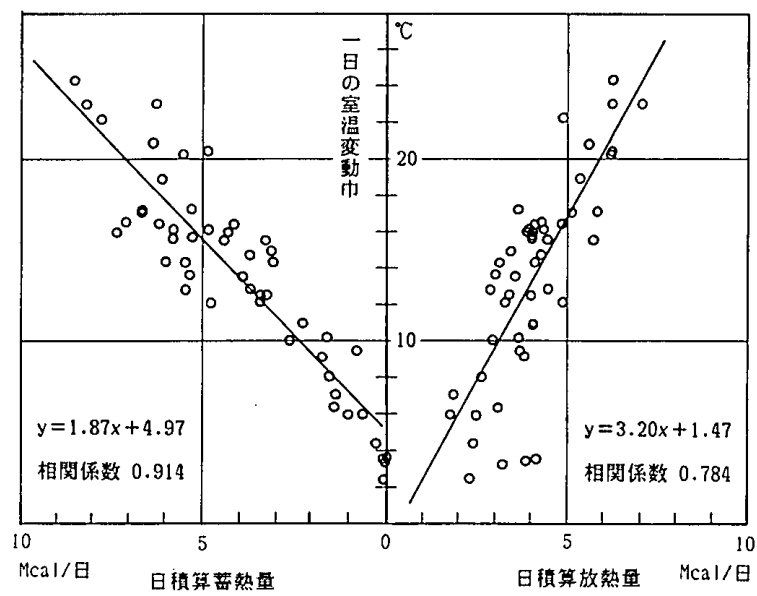

図 17 一日の室温変動幅と日積算蓄放熱量の関係

量より多いこともあれば少ないこともあるのはこのため である。

次に，蓄熱量と放熱量の差を，この日の透過日射量に 対する蓄熱量の割合との関係からみると図 15 のとおり である。図によれは，透過日射量に対する蓄熱量の割合 がおよそ $70 \%$ 以上ではその日は蓄熱量の方が多く, 70 \% 以下では放熱量の方が多い傾向にあることが判る。

\subsection{3 蓄放熱量と日平均室温および室温変動幅の関} 係

蓄放熱量と外気温基準の日平均室温の関係を図 16 に, 蓄放熱量と室温変動幅の関係を図 17 に示す。いずれも 正の相関を示しているが，日平均室温は放熱量との相関 が強く, 室温変動幅は蓄熱量との相関が強い。

\section{5. まとめ}

本報では，熱的性能が同一であることが確かめられた $2 つ$ 試験室を用いて，一方の室には休全面にレンガを $30 \mathrm{~cm}$ の厚さに一様に重ね，他方の室は木造床として両 室の熱的性能の比較を行い，次に，レンガ床の蓄放熱量 を推定して，それらより，パッシブソーラシステムとし ての蓄熱床方式の性能を検討した。実験結果より得られ た知見は以下のとおりである。

（1）レンガ床を施した室の室温は木造末の室の室温 より日中低く逆に夜間は高い。本実験における冬期 (11 月下旬）の測定例では, 雨室温の差は最大で日中 $18^{\circ} \mathrm{C}$,
明け方は $7^{\circ} \mathrm{C} に$ 達した。また，室温の最高および最低 を示す時刻は雨室で一致し，レンガ床の蓄熱によるピー ク時のタイムラグに差は認められなかった。

（2）䍔天日を含む冬期（11月下旬）の5日間を対 象とした場合，厚さ $30 \mathrm{~cm}$ のレンガ床を持つ室の熱損 失係数 $K_{F}$ は $3.09 \mathrm{kcal} / \mathrm{m}^{2} \mathrm{~h}^{\circ} \mathrm{C}$, 有効熱容量 $Q_{R}$ は 832 $\mathrm{kcal} /{ }^{\circ} \mathrm{C}$ と計算された。この有効熱容量の值は木造床の 室の 5 倍であり，使用したレンガの総熱容量の $56 \%$ に 相当した。なお，異なる期間（1月中旬一下旬）の 5 日 間を対象とした計算結果によれは，用いたデータによっ て,$\quad K_{F}$ は $1.39 \sim 2.33 \mathrm{kcal} / \mathrm{m}^{2} \mathrm{~h}^{\circ} \mathrm{C}, \quad Q_{R}$ は $650 \sim 1238$ $\mathrm{kcal} /{ }^{\circ} \mathrm{C}$ となった。また，30日間のデータを用いて計 算すると， $K_{F}$ は $2.05 \mathrm{kcal} / \mathrm{m}^{2} \mathrm{~h}^{\circ} \mathrm{C} ， Q_{R}$ は $709 \mathrm{kcal} /{ }^{\circ} \mathrm{C}$ となり，これらの值が計算期間の気候条件によって左右 されることが推定された。

（3）年間を通してみると， $30 \mathrm{~cm}$ 厚さのレンガ床を 持つ室は木造床の室に比べて外気温基準の日平均室温は ほぼ等しいが,一日の室温変動幅は約 $1 / 2$ に抑えられる。 また, 一日の室温変動幅は両室ともその日の透過日射量 と非常に高い相関を示した。

（4）レンガ床は晴天日において日中日射熱を蓄熱し 夜間放熱している。その蓄熱量, 放熱量を実測值に基づ く3 種類の方法で推定した結果それらはほぼ同様の傾向 となった。本実験の場合，夜間におけるレンガ床の放熱 量はその日の日中が晴天であれば約 $300 〜 400 \mathrm{kcal} / \mathrm{h}(20$ 〜 $\left.30 \mathrm{kcal} / \mathrm{m}^{2} \mathrm{~h}\right)$ となった。

（5）レンガ床の日積算蓄熱量は，日積算透過日射量 に対して正の相関を示すが，本実験の場合， $5000 \mathrm{kcal} /$ 日以上の透過日射量に対してその 40 90\%の範囲にば らついており，この割合は平均するとおよそ $70 \%$ で あった。

（6）本実験におけるレンガ床の日積算放熱量は，そ の日の積算蓄熱量が 0 10000 kcal/日とばらつくのに 対して，3000〜7000 kcal/日の間に全データの $85 \%$ が 入っていた。また，日積算透過日射量に対する日積算蓄 熱量の割合がおよそ $70 \%$ 以上であると日中の積算蓄熱 量の方が夜間の積算放熱量より大きくなり，70\%以下 であるとその逆となる傾向がみられた。なお，日平均室 温は放熱量と, 室温変動幅は蓄熱量との相関が強いこと が示された。

\section{あとがき}

本研究は, 昭和 56,57 年度文部省科学研究費補助金, エネルギー特別研究，自然エネルギーの研究，太陽工ネ ルギー利用の研究 (研究代表者:木村建一, 研究分担者 : 長谷川房雄), 研究分担課題「パッシブソーラシステ ムのエネルギー評価に関する研究」による。

\section{注}

1) レンガ 1 個 $(21 \times 10.5 \times 6 \mathrm{~cm})$ あたりの重さは $2.43 \mathrm{~kg}$ 
でありA 室ではこれを 3024 個使用した。

2) ベニヤ板と断熱材の比熱を $0.3 \mathrm{kcal} / \mathrm{kg}^{\circ} \mathrm{C}$, 密度をそれ ぞれ 550,30 (いずれも $\left.\mathrm{kg} / \mathrm{m}^{3}\right)$ とした。

3）室内の南側と北側の温度測定か所は, 当初, 室を南北方 向と東西方向に 2 分したそれそれれのぼ中心に計 4 か所 予定していたが, 東西方向の温度分布が非常に少ないの で, 北西側および南東側の点については測定か所から取 り除いた。また，床の土間コンクリートの部分には，地 中クールチューブの室内側への立ち上り管（吹出口その ものは断熱材の蓋で閉じている) があるため, その部分 を避けて, 図1に示す位置に設定した。

4）レンガ床である A 室の中で, 日中, 最も温度の高い部分 は妻壁の日射が当たる部分（非蓄熱部位）で，室温より も最大 $12^{\circ} \mathrm{C}$ (午後 2 時) 高くなっており, それらの部分 からの熱の供給によって室温が上昇するものと考えられ る。ただし, 太陽高度が高い季節では床面への日射強度 が大きくなるので，その場合には，日射の当たる林レン ガ表面の温度は室温より高くなり, 日中, レンガ面から も熱が室内空気へ供給される。例えば, 昭和 57 年 3 月 14 日の測定結果によれば, 南側床レンガ表面の温度は室 温よりも, 一日中, $5 \sim 9^{\circ} \mathrm{C}$ 高く, その差の最大値は正午 頃に表れる。

\section{本論文に関連する既発表論文}

1）長谷川房雄, 木村建一, 吉野 博, 石川善美, 松本 博 : 試験家屋を用いたパッシブソーラーシステムの性能評 価に関する研究, その 4, 蓄熱床と蓄熱間仕切壁の効果 及びブラインドの性能実験, 日本建築学会東北支部研究 報告集, 第 39 号, 昭和 57 年 2 月

2) F. Hasegawa, K. Kimura, H. Yoshino, Y. Ishikawa and H. Matsumoto: Performance Evaluation of Passive Solar Systems Using a Tandem-Type Test House,
Fundamental Performance of Test House and Evaluation of Brick Storage Systems, Progress in Passive Solar Systems, American Solar Energy Society, 1982

3）長谷川房雄, 木村建一, 吉野 博, 石川善美, 松本 博 : 試験家屋を用いたパッシブソーラーシステムの性能評 価に関する研究，その 7, 蓄熱休方式に関する二，三の 考察, 日本建築学会東北支部研究報告集, 第 40 号, 昭和 57 年 11 月

4）長谷川房雄, 木村建一, 吉野 博, 石川善美, 松本 博 : 試験家屋を用いたパッシブソーラーシステムの性能評 価に関する実験的研究，その 2 , 各種蓄熱方式の性能比 較実験, 日本太陽エネルギー学会, 第 8 回研究発表会講 演論文集, 昭和 57 年 12 月

参考文献

5）松尾 陽：测定にもとづく室温予測および暖房性能の評 価法について, 日本建築学会大会学術講演梗概集, 昭和 51 年 10 月

6）岡 建雄：太陽熱のパッシブ利用に関する研究, 第 1 報, 小実験空に取り付けられたパッシブシステム, 空気調和・ 衛生工学会論文集, 第 21 号, 昭和 57 年 2 月

7）須永修通，伊藤值明：冬期の南面開口部からの日射熱利 用における建物の熱容量と室内気候形成に関する研究, テストセルによる比較実験, 日本建築学会環境工学論文 集, 第 5 号, 昭和 58 年 11 月

8）松尾 陽, 柳原隆司, 伊藤民雄, 井上 隆, 黒本英智 : パッ シブソーラーシステムの性能評価に関する研究，その 1 , 実験概要及びシミュレーションモデルの検討，日本建築 学会大会学術講演梗概集, 昭和 59 年 10 月

9）長谷川房雄, 木村建一, 吉野 博, 石川善美, 松本 博 :パッシブソーラーシステムの性能を評価するための試 験家屋の熱的性能と基礎実験，日本建築学会論文報告集， 第 361 号, 昭和 61 年 3 月 


\section{SYNOPSIS}

UDC : $697.3: 697.11: 728.011$

\section{EXPERIMENTAL STUDY ON THERMAL STORAGE FLOOR SYSTEM OF PASSIVE SOLAR SYSTEMS USING AN ACTUAL TEST HOUSE}

by Dr. FUSAO HASEGAWA, Prof. of Tohoku Institute of Technology, Dr. KEN-ICHI KIMURA, Prof. of Waseda Univ., Dr. HIROSHI YOSHINO, Associate Prof. of Tohoku Univ., Dr. YOSHIMI ISHIKAWA, Research Associate of Tohoku Univ, and Dr. HIROSHI MATSUMOTO, Research Associate of Tohoku Univ., Members of A.I.J.

This paper describes the experimental results on the performance evaluation of the thermal storage floor system using a tandem-type test house. For the purpose of examining the performance of the thermal storage floor, one test room (Room A) is furnished with a brick floor $30 \mathrm{~cm}$ in depth and the other one (Room B) has a wooden floor, the crawl space of which is ventilated naturally. The effect of thermal storage floor is evaluated by comparing the indoor temperature profiles of the two rooms.

Secondly, this paper also shows the amount of heat absorbed and released by the brick floor as estimated using the measured temperature of several points in the room.

The results of the experiments are shown as follows.

(1) The air temperature of the Room A with a brick floor is about $15^{\circ} \mathrm{C}$ lower at the maximum during the day and $7^{\circ} \mathrm{C}$ higher at the maximum during the night than that of Room $\mathrm{B}$ with a wooden floor. But there is no difference in the peak time of the room temperature between the two room.

(2) The daily air temperature swing of Room A is about $1 / 2$ times smaller all the year round than that of Room B.

(3) The brick floor is absorbing the solar radiation while the sun is shining and releases the heat to the room air during the night and during the sunless days. The rate of heat transferred in the night is estimated to be about $300 \sim 400 \mathrm{kcal} / \mathrm{h}\left(20 \sim 30 \mathrm{kcal} / \mathrm{m}^{2} \mathrm{~h}\right)$ if it is sunny day.

(4) The effective thermal capacity of Room A with a brick floor is calculated to be about $830 \mathrm{kcal} /{ }^{\circ} \mathrm{C}$. This value is 5 times larger than that of Room B with a wooden floor and corresponds to $56 \%$ that of the gross thermal capacity of a brick. 